Crossroads. PC: (CC) Mitya Ilyinov.

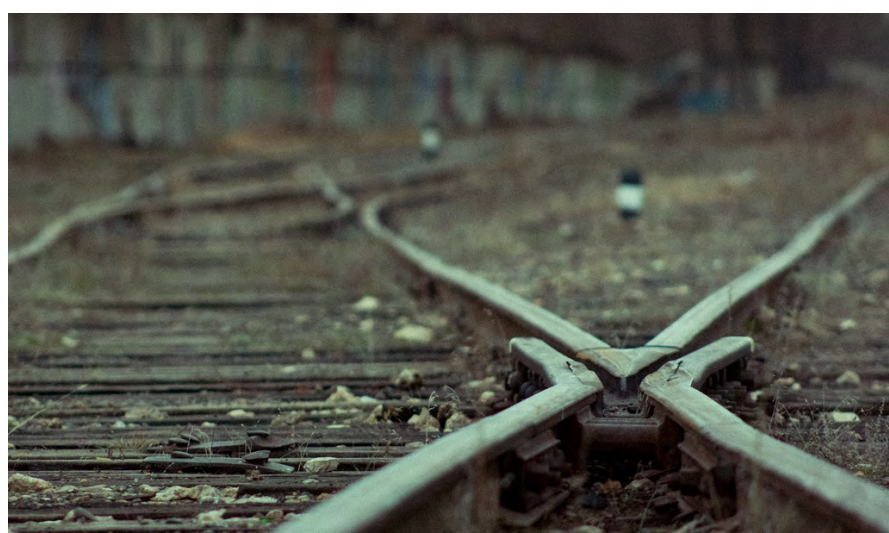

\section{The Third Road \\ Where Will Xi Jinping Go in 2022?}

arlier this year, two veteran analysts of Chinese politics, Richard McGregor and Jude Blanchette (2021), published a comprehensive report, laying out four possible scenarios for the next leadership succession in China's new era. In two of these scenarios, Xi Jinping is out of the picture as the result of either a coup or 'unexpected death or incapacitation'. In the other two, he stays in power either by extending his tenure as the General Secretary of the Chinese Communist Party (CCP) to a third term or by retiring from that office but continuing to rule behind the scenes.

Below I outline a third path Xi could take to stay in power: reactivating the office of the Chairman of the Party Central Committee (hereinafter Party Chairman) at the twentieth CCP Congress in 2022. The reasons for taking this path are threefold. First, the office would not be new, created from scratch, but would be based on precedent. This would not only help to build legitimacy but also draw a roadmap of how to get there. Second, the office would provide Xi with the best solution to deal with the succession issue. Third, two developments signal that the Party is geared towards this political move. I will explain them in turn.

\section{Historical Precedent}

In the centenary of CCP history, the Party Chairman is de facto the only office of power that is held by an individual who is not bound by the founding organisational principle of the Party-that is, collective decision-making. So far, three CCP leaders have held that position: 
The CCP's Charter has

never specified the

scope of power the

Party Chairman can

wield, but records of

Party documents reveal

that Mao enjoyed final

decision-making power

(Politburo 1943).
Mao Zedong (1945-76), Hua Guofeng (1977-81), and Hu Yaobang (1981-82). The office was created for Mao in 1945 at the seventh Party Congress. It was passed on to Hua after Mao's death, following a decisive coup against the 'Gang of Four' led by Hua himself and a few other Party leaders. Having obtained the supreme leadership, Hua, however, did little to strengthen his power base. Hence, when the opposition rallied against him, he resigned without putting up much of a fight, unable to finish even one term. The office was subsequently passed on to $\mathrm{Hu}$, for the sake of continuity, only to be dissolved one year later when the eleventh Party Congress was held in 1982.

The CCP's Charter has never specified the scope of power the Party Chairman can wield, but records of Party documents reveal that Mao enjoyed final decision-making power (Politburo 1943). Before Mao took that office in 1945, he had already been elected as the chairman of the Central Party Secretariat based on a proposal presented to the Politburo by Liu Shaoqi in 1943 (Li 2007). The Central Secretariat at that time was nominally an office operating under the Politburo, but in effect it functioned more like an executive committee of the latter and like the Politburo Standing Committee of today.

Two years later, after Mao was inaugurated as the Party Chairman, the office of the Central Secretariat Chairman ceased to exist. As Party Chairman, Mao made it clear that final decision-making power would stay with him. This is revealed in a written instruction he sent to Liu Shaoqi and Yang Shangkun in 1953-a document included in the fifth volume of Mao Zedong's Selected Works. It reads: 'From now on, all documents and telegraphs that are issued under the name of the Party Centre have to be reviewed by me first before circulation. Otherwise, they are invalid. Please bear it in mind' (Mao 1977).

\section{A Solution for Succession}

One can be worried about the vision Xi Jinping has for China's future and question its virtue and intentions, but no-one can deny he has a vision. He has a blueprint for the Party to lead the country to material prosperity and civilisational rejuvenation by 2049. It is difficult to imagine that Xi, an exceptionally shrewd political ruler who projects the future in centenary terms, would let the succession issue somehow slip his mind. Succession must happen at some point. The question is, what is the best way to administer it?

The reactivation of the Party chairmanship would seem to provide the best solution for $\mathrm{Xi}$, as it would allow him to achieve two goals simultaneously: to continue to rule and to micromanage the succession process. For the first goal, there is no term limit on the office of Party Chairman-either in written rules or in unwritten conventions. The Party chairmanship is part of the 'trinity' of offices-an 
For the second goal, the new office would allow $\mathrm{Xi}$ to set in motion the search for, and grooming of, an heir. The successor could be coronated at a pace and in a manner that $\mathrm{Xi}$ finds most comfortable, thanks to the many options the reactivated office would open to him. arrangement presented as an established CCP 'convention' by Jiang Shigong (2008), a Schmidtian constitutional scholar who seems to have the ear of the Party's decision-makers (Buckley 2020).

For the second goal, the new office would allow Xi to set in motion the search for, and grooming of, an heir. The successor could be coronated at a pace and in a manner that Xi finds most comfortable, thanks to the many options the reactivated office would open to him. To start with, the general secretary's position would be vacant. As such, it could be used to groom the heir-designate under the direct watch of the chairman. If the chairman wanted to prolong the search, he could revoke the position of general secretary so that a few equal candidates could compete within the Politburo Standing Committee. In addition, he may also consider nominating a heir when he was ready by appointing a Deputy Party Chairman, as Mao did.

Granted, the reactivation of the Party chairmanship cannot guarantee a stable transition of power. As demonstrated by Mao himself, the successor may be deposed and replaced later by the chairman because he has changed his mind. Alternatively, the successor could be ousted by some two-faced acolyte whose ambition outweighs their loyalty and is waiting to bounce as soon as the chairman is out of the picture. But, in an autocratic regime with no genuine commitment to constitutionalism and the rule of law, nothing can guarantee a secure tenure, let alone life tenure, for any leader or his successor, no matter how the succession process is designed. The reactivation of the office of Party Chairman would, however, provide a convenient structure that allows the incumbent leader to control the succession process and accommodate trial and error.

\section{Signs of Preparatory Moves}

The first sign of Xi's intention to stay in power after 2022 is, of course, the constitutional amendment made in 2018, which lifted the term limit for the head of the state-that is, the Chairman of the People's Republic of China. This move was Xi's first overt preparatory measure to stay in power after his second term. It indicates either or both of two things: first, that he greatly values the ceremonial role of the head of the state; and second, that he has concerns about the possibility that an overambitious occupant of this office, if it must be passed from him to someone else due to the term limit, could turn its ceremonial functions-for instance, promulgating laws, appointing and dismissing leaders of state institutions, signing treaties with foreign countries ( $\mathrm{Li} 2019 \mathrm{~b}$ )-into veto powers, thereby significantly weakening the political dominance of Xi himself as the head of the Party. 


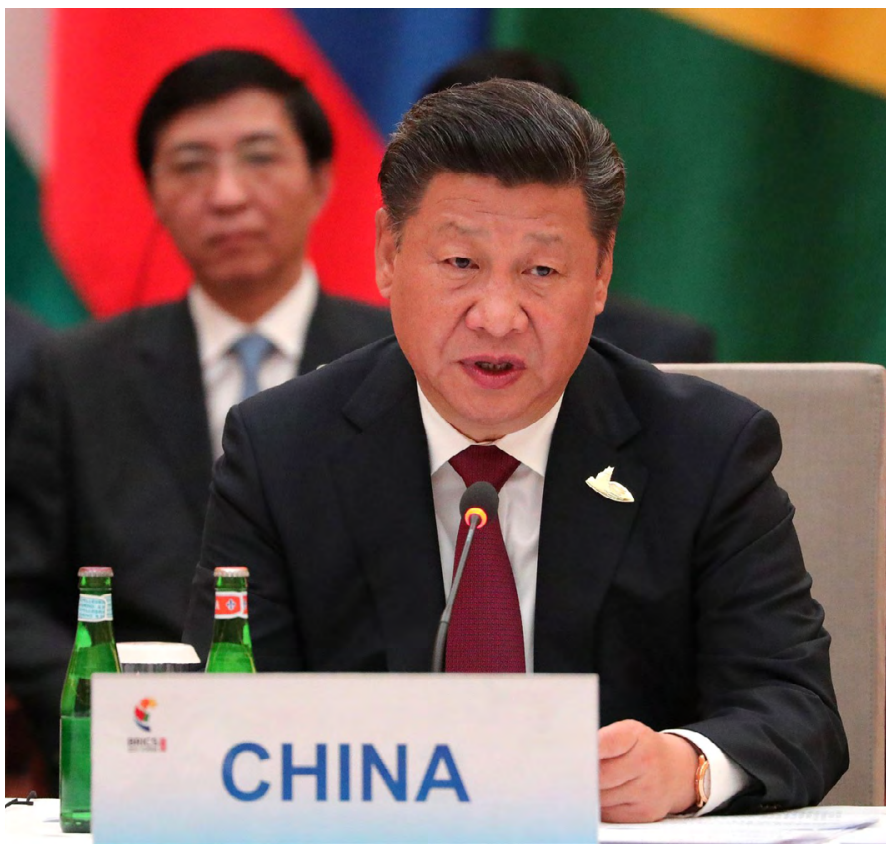

Xi Jinping in 2017.

PC: (CC) Kremlin.ru.

While this does not necessarily signal an intention to resurrect the Party chairmanship, a truly compelling signal that this might be the plan is the unfolding of an exceptionally intensive and vigorous national ideological campaign to establish 'Xi Jinping Thought'. The effort the Party has taken to push this campaign bears great resemblance to the playbook Mao used before the same office was first created for him at the seventh Party Congress in 1945.

A memoir by He Fang (2019) entitled Notes on Party History: From Zunyi Conference to Yan'an Rectification (党史笔记一从遵义 会议到延安整风) revealed that to have a namesake ideology is not only a means to canonise policies, orient actions, and identify and dispel heretics, but also an end in and of itself. According to He, who participated in the Yan'an Rectification Campaign (1941-45) and later became political secretary to Zhang Wentian (who was the CCP General Secretary from 1938 to 1943 and a target of the campaign), there is a tradition observed by communist movements with regard to the elevation of a supreme leader. According to He, to become the supreme leader of a communist party, one needs not only to prove one's political, military, and administrative skills, but also to demonstrate one's intellectual capacity and establish oneself as a Marxist theorist.

Mao was not considered a theorist before the rectification campaign was launched (He 2019: 140). According to He's finebrushed account, at that time, Mao had been dismissed by his colleagues as only a 'doer' ( 实千家) and not a 'theorist' (理论家). 
The Yan'an campaign completely changed that. In the first phase of the campaign, the Party enforced mandatory study sessions of Party classics, of which Mao's own works formed a predominant portion (He 2019; Tan 2014), and criticism and self-criticism were mainly used for indoctrination. Not long after, 'enhanced measures' were added to compel self-incriminating confessions and to establish guilt in the name of 'rescuing' those who had slipped (Gao 2019).

At the end of the campaign, Mao emerged as a Chinese Marxist theorist, credited with the unparalleled achievement of having Sinicised Marxism (He 2005). The campaign culminated with the 'Resolution of Several Historical Issues' (关于若千历史问题 的决议) passed by the last plenum leading up to the seventh Party Congress. This elaborate account of CCP history rendered Mao as an infallible political leader and established his absolute authority over all aspects of Party affairs. It also sealed the position of Party Chairman for Mao immediately after.

\section{Xi Jinping's Moves}

Xi's ideological campaign started at the beginning of his first term. As I have analysed elsewhere (Li 2019a), the campaign was synchronised in speed and content with his signature anticorruption campaign. During that campaign, Party members were required to study a collection of Xi's ideological works, which at that time were tentatively labelled the 'Spirit of Important Speech Series by the Party General-Secretary Xi Jinping' (习近平总书记系列重要讲话 精神). After Xi had consolidated power at the end of his first term, Party propaganda outlets started to refer to the growing volume of his ideological works as 'Xi Jinping Thought on Socialism with Chinese Characteristics in the New Era' ( 习近平新时代中国特色社 会主义思想, or 'Xi Jinping Thought'), which was introduced into the CCP's Charter at the nineteenth Party Congress.

Since 2017, the Party-State's propaganda machine has been running at full throttle to canonise Xi's words and deeds and to substantiate the theory of Xi Jinping Thought. At the time of writing, Xi Jinping Thought has covered close to 20 public policy fields and is presented as the 'latest achievement of the Sinification of Marxism' (马克思主义中国化最新成果; see He 2020). It has been turned into textbooks and training materials for mandatory study by schoolchildren, college students, politicians, and civil servants. In at least 10 elite universities, research institutes have been established that are solely dedicated to advancing this new discipline (Chen et al. 2018). According to its online database, the National Social Sciences Fund, the most generous and prestigious funding body for social sciences in China, sponsored over 370 research projects with Xi Jinping's name in the title between 2014 and 2020. 
It is likely no coincidence that at the time of writing in mid-October 2021, the Party has just announced that a resolution on an updated narrative of the Party's history will be delivered by the current Central Committee at its Sixth Plenum, which will convene in early November. It took Mao less than two months from being heralded the master of Sinicised Marxism to being inaugurated as the Party Chairman. Time is on Xi's side because the twentieth Party Congress is still one year away. The Party believes history is a mirror. Is the mirror also a crystal ball? Only time will tell. 
This text is taken from Made in China Journal: Volume 6, Issue 2, 2021, edited by Ivan Franceschini and Nicholas Loubere, published 2021 by ANU Press, The Australian National University, Canberra, Australia.

doi.org/10.22459/MIC.06.02.2021.03 